\title{
What do we [not] know about technology entrepreneurship research?
}

\author{
João J. M. Ferreira ${ }^{1,2}$ - Fernando A. F. Ferreira ${ }^{3,4}$. \\ Cristina I. M. A. S. Fernandes ${ }^{2,5}$ - Marjan S. Jalali ${ }^{3}$. \\ Mário L. Raposo ${ }^{1,2}$ - Carla S. Marques ${ }^{6,7}$
}

(C) Springer Science+Business Media New York 2015

\begin{abstract}
This study aims to review what we do (and do not) know about technology entrepreneurship (TE) research to date. Based on a categorized bibliometric analysis resulting from a systematic review of 135 scientific articles published in refereed journals over the past 27 years (1986-2013), we identify the core domains of TE, its intellectual structure, the scientific journals with a major impact in this field of research, and the affiliation and collaboration networks within it. Specifically, through a detailed
\end{abstract}

João J. M. Ferreira

jjmf@ubi.pt

Fernando A. F. Ferreira

fernando.alberto.ferreira@iscte.pt

Cristina I. M. A. S. Fernandes

kristina.fernandes81@gmail.com

Marjan S. Jalali

marjan.jalali@iscte.pt

Mário L. Raposo

mraposo@ubi.pt

Carla S. Marques

smarques@utad.pt

1 Department of Business and Economics, University of Beira Interior, Covilhã, Portugal

2 NECE Research Unit, Covilhã, Portugal

3 ISCTE Business School, BRU-IUL, University Institute of Lisbon, Lisboa, Portugal

4 Fogelman College of Business and Economics, University of Memphis, Memphis, TN 381523120 , USA

5 Polytechnic Institute of Castelo Branco, Castelo Branco, Portugal

6 Department of Economics, Sociology and Management, University of Trás-os-Montes e Alto Douro, Vila Real, Portugal

7 CETRAD Research Unit, Vila Real, Portugal 
analysis of article co-citations within the TE area, this study provides co-citation networks of authors, journals, and their respective clusters, revealing their rankings in terms of contributions to the TE literature. This comprehensive analysis can be used to enhance our understanding of TE and support further research in this field.

Keywords Technology entrepreneurship (TE) - Knowledge transfer · Bibliometric analysis $\cdot$ Co-citations $\cdot$ Intellectual structure $\cdot$ Scientific journals $\cdot$ State of the art

\section{Introduction}

Entrepreneurs play a fundamental role in modern economy, as they are responsible for pioneering initiatives and business creation, which allow for sustainable economic development ( $c f$. Audretsch et al. 2006; Schramm 2006; Baumol et al. 2007). Indeed, entrepreneurs are frequently characterized as both catalysts of new ideas and as leaders who put those ideas into practice (see Baumol 1968, 1993, 2005). This assumption is complemented by Casson (1982, 1987, 1997, 2003), who argues that entrepreneurs create companies explicitly to deal with the complexity of the business environment, developing goods and services that aim to meet market needs. Innovators, on the other hand, tend to see company results as a residual of the activity developed, since for them the decision to innovate stems, above all, from the intention to commercialize an invention (Spulber 2009, 2011; Gans and Stern 2003). This supports the classic approach to entrepreneurial innovation presented by Schumpeter (1934), who claimed that the innovator represents the will and the action required to innovate. Within this reasoning, the decision to innovate is associated with two domains of action: entrepreneurship and technology transfer ( $c f$. Spulber 2011).

Technology transfer has frequently been associated with knowledge techniques that allow individual and organizational know-how to be shared among individuals, companies, universities, public research institutes and other economic agents ( $c f$. DiMaggio and Powell 1983; Melkers et al. 1993; Storper 1995). Walsh and Kirchhoff (2002) argue that certain forms of technology transfer occur between and within organizations, and that the dynamics behind such processes justify significant attention, which has recently been devoted to the technology entrepreneurship (TE) phenomenon; i.e., the body of knowledge that explicitly addresses the role of human initiative in the development of new technologies (Garud and Karnøe 2003). The remarkable progress in this field of research has required both its terminology and content to be reviewed, and two publications have already begun this work (Phan and Foo 2004; Beckman et al. 2012). Specifically, Phan and Foo (2004) organized a special issue of the Journal of Business Venturing, in which six articles were selected revealing a great diversity of methodological and pedagogical theory in this rich and promising field of research. Beckman et al. (2012), in turn, put together a special issue of the Strategic Entrepreneurship Journal, in which a collectively approach to the role that entrepreneurs should play in the heart of technology ventures was proposed. According to the authors, entrepreneurs' talent, experience and actions are particularly influential when complex technological advances play a critical role in business. It is worth noting, however, that all the papers published in these two special issues have a narrow focus in 
terms of topic and number of publications analyzed. No prior evidence of a systematic literature review using bibliometric tools in this area has been found.

Underlying the scientific structure of a research field, is typically a network of informal communication links among the most influential researchers in the area, which is also important to analyze. In light of these considerations, and to foster further understanding of this phenomenon, our study aims to map scientific publications, intellectual structures and research trends in the area of TE, addressing the broad question: "What do we know about TE research?", and aiming at the same time, to identify what we have still to learn about this research. Specifically, we propose to: (i) identify the progress achieved in the TE research field; (ii) determine the research lines that constitute the intellectual framework in this field; and the scientific journals with the highest impact in the area; and (iii) identify promising topics and themes for further research in TE, based on what we do not yet know about the field.

Methodologically, this study builds on previous literature to deepen our understanding of TE research. Based on a systematic review of 135 scientific articles about TE, a categorized bibliometric analysis for the period from 1986 through 2013 is presented. Through this analysis, the study also provides researchers with a solid basis for positioning current contributions and detecting new lines for future research. This is important in terms of research development because most existing studies are fairly limited and, therefore, current knowledge on TE has not been driven efficiently.

The remainder of the paper is structured as follows. The next section presents an overview of the literature on TE. The following section presents the methodology and discusses the results in terms of TE core areas and the resulting networks. The last section concludes the paper, presenting observations and suggesting avenues for future research.

\section{Technology entrepreneurship}

Baumol (1968) argued that studying companies without considering entrepreneurship would be like studying Shakespeare after expunging the Prince of Denmark from the discussion of Hamlet. It should not be surprising, therefore, that researchers have come to pay particular attention to entrepreneurship, and the creation of new companies over the years (i.e., who creates them, when, where and why?; for further details, see Hébert and Link 1982, 2009; Aldrich and Fiol 1994; Zucker et al. 1998; Stuart et al. 1999; Swedberg 2000; Parker 2005; Landström 2005; Landström and Benner 2010).

Entrepreneurship involves discovery and creation, boosting numerous business opportunities. Widely known as the social construction of technological systems (SCTS), entrepreneurship provides detailed insights about the micro-processes associated with emerging technology (Tushman and Anderson 1986; Bijker et al. 1987; Venkataraman 1997; Shane and Venkataraman 2000). These insights suggest that human action spreads among economic agents (also known as actors), specifically among those who are involved in the technology transfer process. Indeed, a recurring theme that runs through the SCTS literature is that technological progress cannot be attributed to a single individual, but must be attributed to multiple actors ( $c f$. Braun and Macdonald 1982; Garud and Van de Ven 1987; Cohen and Levinthal 1990; Latour 1991; Bijker and Law 1992; Karnøe 1993; Aldrich 1999; Bhide 2000). These actors 
include not only those who create and discover new ideas, but also those who develop complementary assets (Teece 1987; Teece et al. 1997), those who participate in institutional forums (Garud and Rappa 1994), and customers who provide critical insights that allow emerging paths to be shaped (Rosenberg 1982; Von Hippel 1986; Kline and Pinch 1996; Tripsas 2001). The presence of several economic agents with different levels of involvement implies that human action is distributed among several individuals. Hence, technological change occurs through a synthesis of new contributions from a number of actors (Usher 1954; Latour 1991). Based on this premise, Mises (1978), Barney (1991), Kirzner (1997), Casson (1995), Harper (1996), Shane (2000), Knight (2002) and Garud and Karnøe (2003) argued that TE is much more than the simple discovery of pre-existing options based on individual alerts or pure speculation about the future. Rather, TE involves creating new options through the re-organization and transformation of existing resources. As defended by Schumpeter (1942), Usher (1954), Venkataraman (1997) and Garud et al. (1998), it is a body of knowledge that explicitly addresses the role of human initiative in developing new technologies. These new technologies allow various activities to be shaped and are responsible for the entrance of new actors, who are mobilized through learning and accumulated knowledge (Garud 1997).

Naturally, in addition to the intrinsic characteristics of the entrepreneur, which lead her/his to create innovations and process technology transfer, thus creating TE, it is also necessary to consider the characteristics of the environment and the demands of the market itself, which can foster (or hinder) the emergence of TE (Nacu and Avasilcăi 2014). This consideration led Beckman et al. (2012) to separate technological entrepreneurship from mainstream entrepreneurship; because of its focus on new opportunities promoted through innovation in science and engineering. The authors considered that TE is closely linked to technological innovation, to emerging markets and to the creation of new products; such that TE is drawn between two major fields: entrepreneurship and technology-based innovation.

In this regard, the importance of the human capital generated by universities for the development of TE has also been emphasized (Wright et al. 2007). Price (1963) applied the term to the existence of informal communication networks among scholars from different institutions, often geographically separated (see also Price 1971; Lievrouw 1989; Zuccala 2006; Teixeira 2011). In light of these considerations, and because remarkable progress has occurred recently in this research field, this paper aims to provide an up-to-date categorized bibliometric overview of the most recent trends in the TE phenomenon.

\section{Bibliometric analysis of the TE literature}

\section{Selection of the articles}

A bibliometric analysis involves the application of a quantitative statistical analysis to publications (e.g., scientific articles) and respective citations. Because it provides data on the level of activity in a certain scientific field, its resulting outcomes can be used to evaluate the research performance of researchers, journals, countries and institutions (cf. Thomsom Reuters 2008). 
The analysis of co-citations is often used to outline the publications in a certain field of research in detail, serving to identify papers with higher impact ( $c f$. Small 1973; Zitt and Bassecoulard 1994). Two documents are considered co-cited when they are cited together in other documents (Smith 1981), and the number of co-citations allows influential authors to be identified and their interrelations to be revealed (White and McCain 1998). According Verbeek et al. (2002), co-citations assume that: (i) quotation implies use; (ii) quotation reflects excellence, significance and impact; (iii) citations are made to improve research; (iv) a cited document is related to the document that cites it; and (v) all citations are equal. Based on these considerations, several studies have demonstrated the validity of co-citation analysis to understand the intellectual structure of a certain field of research ( $c f$. Di Guardo and Harrigan 2012).

In this work, upstream and downstream co-citation analyses were performed. We analyzed articles referenced by the papers included in our sample and, in addition, articles that cited the analyzed articles. These co-citation analyses served to identify two networks of articles: (i) the network allusive to articles on technological entrepreneurship; and (ii) the network related to the underlying contributions resulting from these research articles. They also served to determine groups of articles by cluster analysis. Finally, publications can also be analyzed at the country level and in terms of international co-authorship (i.e., in the case of organizations from different countries). The results in this case are displayed by representing the country of the author as a node and the relationships of co-authorship as a link between nodes. In the present study, the clusters and respective networks of references were obtained following the methodological guidelines proposed by Van Eck and Waltman $(2009,2010)$ and Waltman et al. (2010). For the analyses, we used the software VOSviewer version 1.5.5 (www.vosviewer.com), which supported the construction of the bibliometric maps.

We collected data from the following indexes: Science Citation Index Expanded (SCI-Expanded), Social Science Citation Index (SSCI) and Arts \& Humanities Citation Index (A\&HCI), compiled by the Thomson/Reuters online database, which contains thousands of scholarly publications and bibliographic information about authors, affiliations and citations. The data collection was conducted through the ISI Web of Science database and involved articles published in journals allocated to the categories of management, business and economics, without the use of any chronological filter. The search terms used (in any part of the publication) were technological entrepreneurship and technology entrepreneurship. The unit of analysis in this study is the publication, while the variables correspond to authors and respective affiliations, journals, number of citations and cited references. The search performed resulted in 135 scientific articles with publication dates between 1986 ( 1 article) and 2013 (11 articles).

\section{The emergence of TE}

Figure 1 shows the number of articles on TE published by year; and the trend suggests that, despite the low number of papers published in 2011, TE is an emerging field of research. Papers in this field first started being published during the second half of the 1980s; and in comparison to the 1990s, the first decade of the 21 st century reveals a great increase in the number of annual publications. Since 2007, this number has been greater than (or equal to) 10 every year except 2011 (in which the number of 


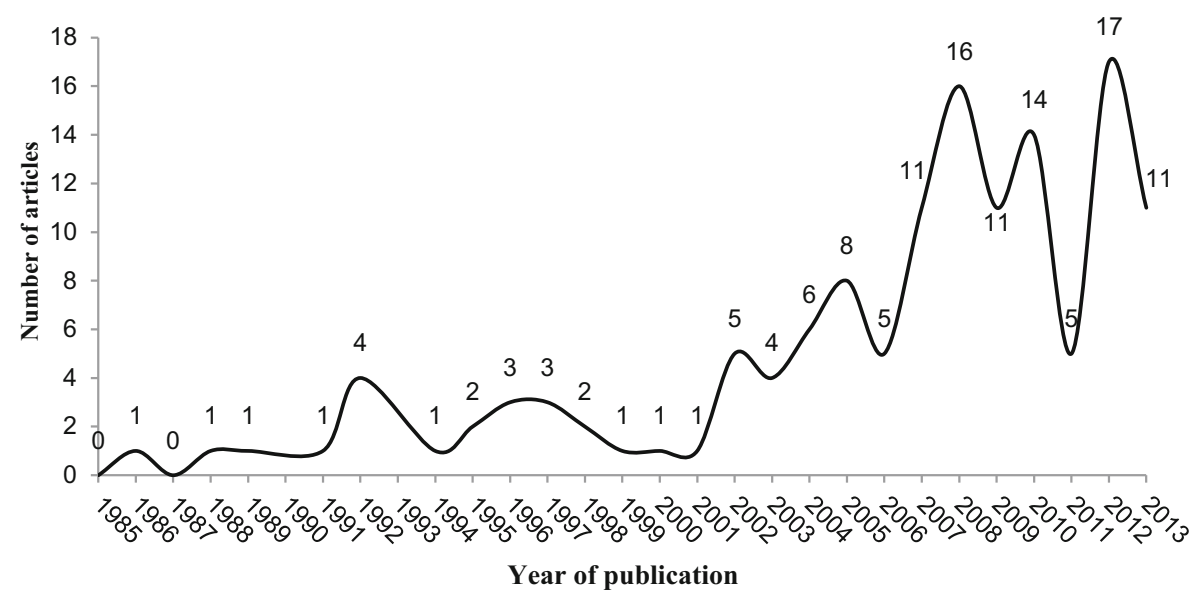

Fig. 1 Number of articles by year of publication

publications was of only five). The years 2008 and 2012 saw the highest number of publications in the field, with 16 and 17 articles published, respectively).

The 135 articles considered in the sample present an average citation rate of $24.1 \%$. However, 68 of the articles have never been cited, and 30 have been cited between one and five times. Table 1 reveals the top-30 ranking of papers in terms of highest number of citations.

The top five studies with the highest number of citations are:

1. Garud, R., \& Karnøe, P. (2003). Bricolage versus breakthrough: Distributed and embedded agency in technology entrepreneurship. Research Policy, 32(2), 277300. (227 citations).

2. Dushnitsky, G., \& Lenox, M. (2005b). When do incumbents learn from entrepreneurial ventures? Research Policy, 34(5), 615-639. (93 citations).

3. Venkataraman, S. (2004). Regional transformation through technological entrepreneurship. Journal of Business Venturing, 19(1), 153-167. (67 citations).

4. Spencer, J., Murtha, T., \& Lenway, S. (2005). How governments matter to new industry creation. Academy of Management Review, 30(2), 321-337. (55 citations).

5. Bahrami, H. \& Evans, S. (1995). Flexible re-cycling and high-technology entrepreneurship. California Management Review, 37(3), 62-89. (55 citations).

In the most cited paper, Garud and Karnøe (2003) approached TE from the perspective that its developments result from the influence of different types of actors who are responsible for emerging technological paths able to generate more knowledge. This perspective was described through a comparative study of the emergence of wind turbines in Denmark and the United States (U.S.). Dushnitsky and Lenox (2005b) focused on the potential benefits of corporate venture capital for innovation, suggesting that corporate venture capital is critical to the generation of innovations that result from entrepreneurial initiatives; and that these initiatives in turn play a fundamental role in a company's innovation strategy. The authors analyzed a panel of 2.289 public companies from 1969 through 1999, and found that increases in corporate venture capital investment were associated with an increase in the number of patents registered. 
Table 1 Most-cited articles in the field of TE

\begin{tabular}{|c|c|c|c|c|c|}
\hline & & $\begin{array}{l}\text { Total } \\
\text { citations }\end{array}$ & & & $\begin{array}{l}\text { Total } \\
\text { citations }\end{array}$ \\
\hline 1 & Garud and Karnøe (2003) & 227 & 16 & Smilor and Feeser (1991) & 17 \\
\hline 2 & Dushnitsky and Lenox (2005b) & 93 & 17 & Antoncic and Prodan (2008) & 16 \\
\hline 3 & Venkataraman (2004) & 67 & 18 & Phan and Foo (2004) & 16 \\
\hline 4 & Spencer et al. (2005) & 55 & 19 & Segal (1986) & 15 \\
\hline 5 & Bahrami and Evans (1995) & 55 & 20 & Mustar and Wright (2010) & 14 \\
\hline 6 & Bruton and Rubanik (2002) & 51 & 21 & Gilsing et al. (2010) & 13 \\
\hline 7 & Teece (1998) & 50 & 22 & Barr et al. (2009) & 13 \\
\hline 8 & Florida and Kenney (1988) & 44 & 23 & Yanez et al. (2010) & 12 \\
\hline 9 & Song and Podoynitsyna (2008) & 42 & 24 & Dodgson (2009) & 12 \\
\hline 10 & Doganova and Eyquem-Renault (2009) & 40 & 25 & Morris and Lowder (1992) & 12 \\
\hline 11 & Maine and Garnsey (2006) & 35 & 26 & Tan et al. (2009) & 10 \\
\hline 12 & Chang and Shih (2004) & 32 & 27 & Kassicieh et al. (1997) & 10 \\
\hline 13 & Neck et al. (2004) & 27 & 28 & Wong (2003) & 9 \\
\hline 14 & Wright et al. (2007) & 23 & 29 & Tomes et al. (2000) & 9 \\
\hline 15 & Shane and Venkataraman (2003) & 20 & 30 & Tierney et al. (2013) & 8 \\
\hline
\end{tabular}

Supporting the Schumpeterian perspective of entrepreneurship, Venkataraman (2004) argued that the intangible factors of entrepreneurship are, by themselves, sufficient to allow local and regional economies to develop. According to the author, governments trying to promote technological entrepreneurship through the injection of corporate venture capital lead to low-quality entrepreneurship. As such, corporate venture capital should be accompanied by seven intangible factors: access to new ideas, models, informal forums, specific opportunities of the region, safe networks, access to large markets and executive leadership. Spencer et al. (2005) provided a classification of the major challenges and opportunities for governments and innovative companies. This was based on network composition and coordination, leading to four types of policies: (i) state corporativism; (ii) social corporativism; (iii) liberal pluralism; and (iv) statenation. The authors concluded that corporativist structures influence governmental capabilities in the diffusion of technology-oriented policies for business innovation and technological entrepreneurship; they also concluded that the strength of state institutions can amplify or undermine government policies and firm strategies. Bahrami and Evans (1995) used the microeconomic foundations of endogenous growth theory to develop the knowledge spillover theory of entrepreneurship. According to this approach, knowledge created endogenously results in knowledge spillovers that allow entrepreneurs to identify and exploit new business opportunities.

The initial sample of 135 scientific articles was reduced to papers with at least 10 citations, resulting in 27 articles quoted 952 times. Based on these 27 contributions, we performed a co-citation analysis and the size of the sample was again reduced to 21 papers. This was because Teece (1998), Chang and Shih (2004), Antoncic and Prodan (2008), Yanez et al. (2010), Morris and Lowder (1992) and Tan et al. (2009) did not present any co-citations. The co-citation analysis served to build the respective network 
(see Fig. 2) and to group the 21 articles into clusters (see Table 2), where cluster 1 stands for the institutional approach, cluster 2 identifies the governemental and financial approach, and cluster 3 stands for the environmental approach to TE.

\section{Evolution and co-citation networks}

Aiming to increase our understanding of the theoretical foundations of the 135 articles included in the sample, we examined the network of papers referenced by those 135 contributions (Fig. 3); this examination reavealed 4.397 references of which 29 had at least five citations. The articles with the highest number of citations were Shane and Venkataraman (2000) (12 citations), Teece (1986) (10 citations), Eisenhardt (1989), Porter (1990) and Shane (2000) (8 citations each).

Regarding authorship, the results showed that 255 authors are responsible for the 135 articles included in the sample. Table 3 shows the 50 most frequently cited authors, as well as the number of articles published and the average citations per article. As can be seen, the most cited authors are Garud and Karnøe (2003) (227 citations), Dushnitsky and Lenox (2005b) (93 Citations) and Venkataraman (2004) (87 citations). As for the authors with higher numbers of articles published, one should highlight Walsh (6 articles), Garnsey (3 articles), Maine (3 articles) and Wright (3 articles).

Following the overall analysis of the 135 articles, we analyzed the number of citations for this particular group of authors. As a result of the co-citation analysis, we obtained 3.009 cited authors, 40 of which were cited at least 10 times. These 40 authors were grouped into clusters as shown in Table 4, giving rise to the network diagram presented in Fig. 4.

spencer jw, 2005, acad ma

segal ns, 1986, technovat neck hm, 2004, j small bu

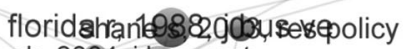

phaneRkatarânhus sento04, j bhargadon a, 1997, admin s

bahrami h, 1995, calif ma

maine e, 2006, res policy

wright $\mathrm{m}, 2007$, entrep th

bruton gd, 28R2, nh, besofe j prod inno

barr sh, 2009 acad manag

mustar p, 2010, j technol

Fig. 2 Co-citation network

gilsing va, 2010, technov

kassicieh sk, 1997, ieee 


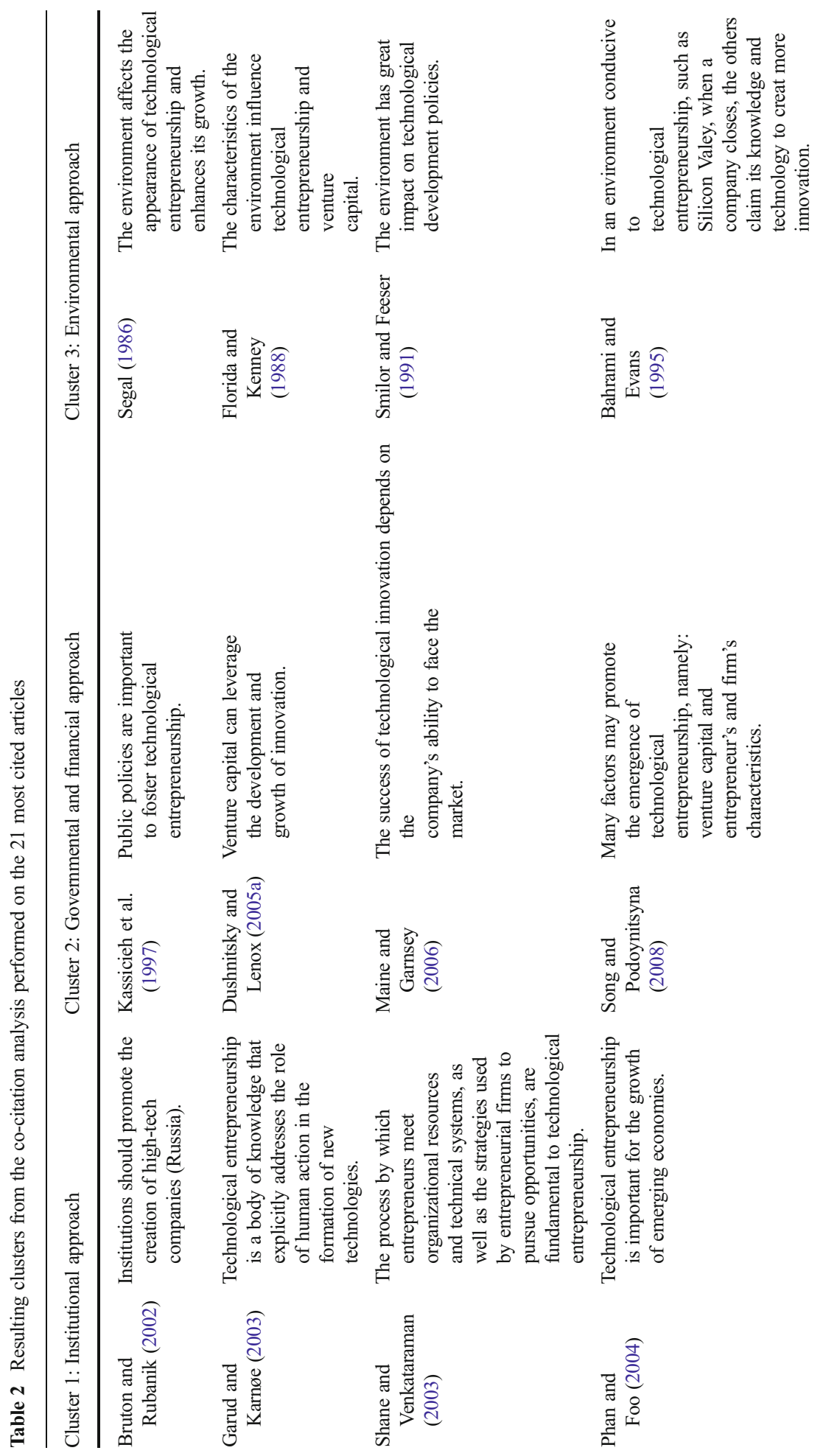




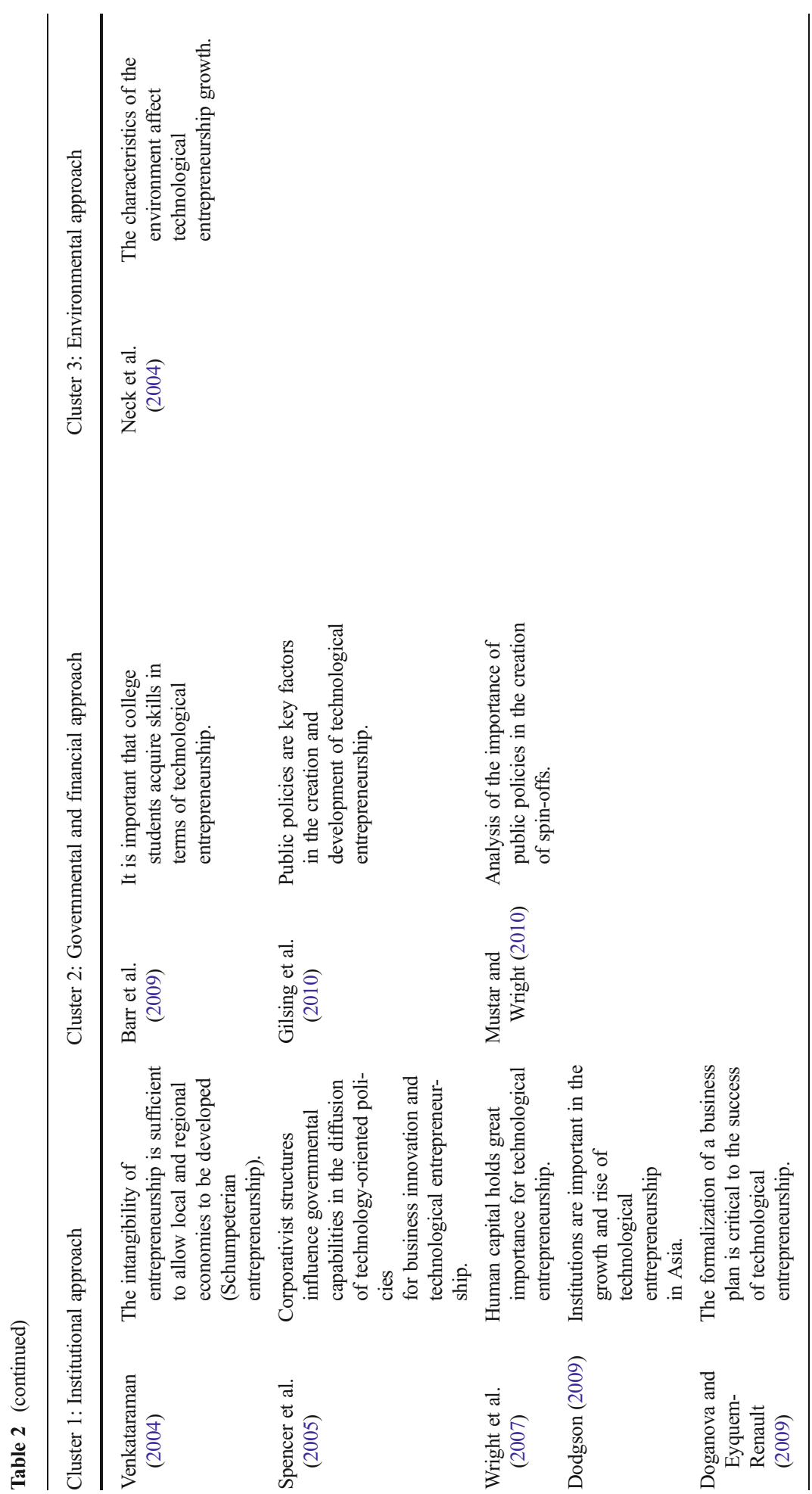




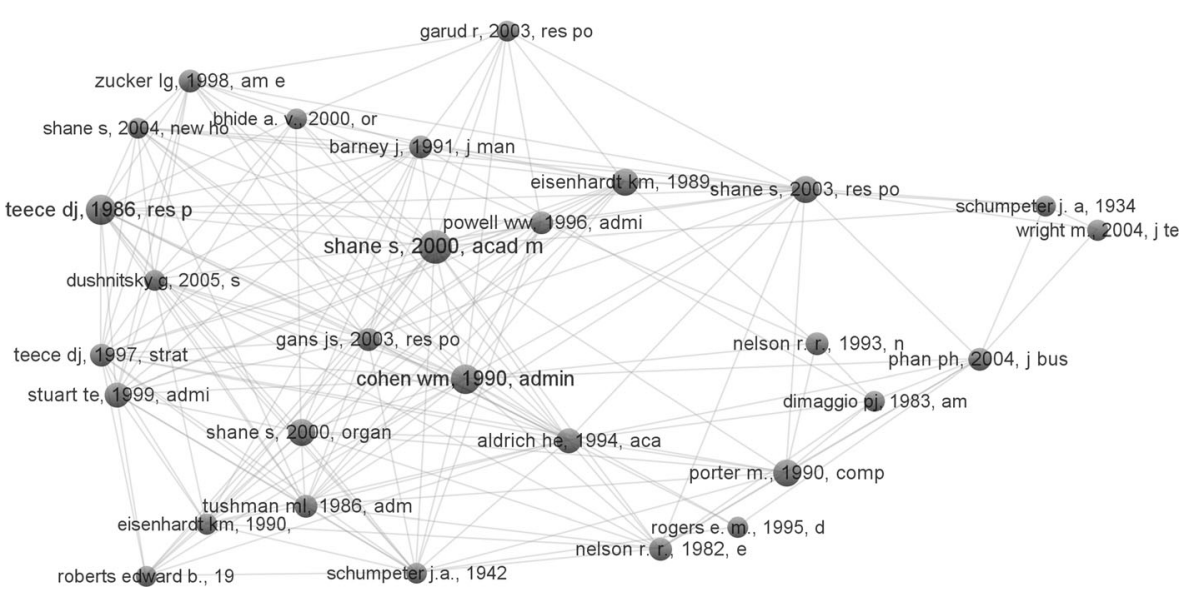

Fig. 3 Network of references cited in the 135 articles and respective clusters

As shown, the authors with the highest number of citations are Shane (53 citations), Schumpeter (34 citations), Eisenhardt (27 citations), and Teece, Wright and Zahra (26 citations).

With regard to the sources, the 135 scientific articles included in the sample were published in 82 academic journals. As can be seen in Table 5, the journals with the highest numbers of citations are Research Policy (424 citations), Journal of Business Venturing (195 citations), Technovation (108 citations), California Management Review (105 Citations) and Academy of Management Review (55 citations). As for the number of papers published, special emphasis should be given to Research Policy and Technovation (both with 8 papers), followed by the Strategic Entrepreneurship Journal (with 7 articles).

Among the 2.177 journals cited by the 135 articles included in the sample, 28 have at least 20 citations. As shown in Table 6, the co-citation analysis for these 28 journals reveals four clusters. The respective network is presented in Fig. 5.

As can be seen, the most frequently quoted journals are Research Policy (224 citations), Journal of Business Venturing (196 citations), Strategic Management Journal (164 citations), Technovation (109 Citations) and Administrative Science Quarterly (95 Citations).

\section{Affiliation and collaboration networks}

When analyzing data from the 158 institutions that underlie the 135 papers published in the field of TE, it is worth noting that the institutions with stronger competence in this field are from the U.S. In particular, as far as number of publications is concerned, universities such as the University of California System, Texas Christian University, University of New Mexico and University of Washington are ranked in the top four places. Institutions external to the U.S. include Glasgow Caledonian University (UK), Imperial College London (UK), University of Cambridge (UK) and University of Nottingham (UK) in Europe; Zhejiang University of Science Technology in China; University of Pretoria in South Africa; and Simon Fraser University in Canada. No institution from Oceania or Latin America appears in the higher echelons of the ranking. Table 7 shows the pairs of institutions that present greater numbers of co-authorships ("invisible colleges"). 
Table 3 Top cited authors in the field of TE

\begin{tabular}{|c|c|c|c|c|c|c|c|}
\hline Authors & $\begin{array}{l}\text { Total } \\
\text { citations }\end{array}$ & $\begin{array}{l}\text { Total } \\
\text { articles }\end{array}$ & $\begin{array}{l}\text { Average } \\
\text { citation } \\
\text { per article }\end{array}$ & Authors & $\begin{array}{l}\text { Total } \\
\text { citations }\end{array}$ & $\begin{array}{l}\text { Total } \\
\text { articles }\end{array}$ & $\begin{array}{l}\text { Average } \\
\text { citation } \\
\text { per article }\end{array}$ \\
\hline Garud, R & 227 & 1 & 227.0 & Cohen, B & 27 & 1 & 27.0 \\
\hline Karnoe, P & 227 & 1 & 227.0 & Corbett, AC & 27 & 1 & 27.0 \\
\hline Dushnitsky, G & 93 & 1 & 93.0 & Meyer, GD & 27 & 1 & 27.0 \\
\hline Lenox, MJ & 93 & 1 & 93.0 & Neck, HM & 27 & 1 & 27.0 \\
\hline Venkataraman, S & 87 & 2 & 43.5 & Walsh, ST & 27 & 6 & 4.5 \\
\hline BahramI, H & 55 & 1 & 55.0 & Phan, P & 26 & 2 & 13.0 \\
\hline Evans, S & 55 & 1 & 55.0 & Ensley, MD & 23 & 1 & 23.0 \\
\hline Lenway, SA & 55 & 1 & 55.0 & Hmieleski, KM & 23 & 1 & 23.0 \\
\hline Murtha, TP & 55 & 1 & 55.0 & Siegel, DS & 23 & 1 & 23.0 \\
\hline Spencer, JW & 55 & 1 & 55.0 & Shane, S & 20 & 1 & 20.0 \\
\hline Bruton, GD & 51 & 1 & 51.0 & Feeser, HR & 17 & 1 & 17.0 \\
\hline Rubanik, Y & 51 & 1 & 51.0 & Smilor, RW & 17 & 1 & 17.0 \\
\hline Teece, DJ & 50 & 1 & 50.0 & Antoncic, B & 16 & 1 & 16.0 \\
\hline Florida, R & 44 & 1 & 44.0 & Foo, MD & 16 & 1 & 16.0 \\
\hline Kenney, M & 44 & 1 & 44.0 & Prodan, I & 16 & 1 & 16.0 \\
\hline Halman, JIM & 42 & 1 & 42.0 & Segal, NS & 15 & 1 & 15.0 \\
\hline Podoynitsyna, K & 42 & 1 & 42.0 & Tomes, A & 15 & 2 & 7.5 \\
\hline Song, $\mathrm{M}$ & 42 & 1 & 42.0 & Mustar, P & 14 & 1 & 14.0 \\
\hline van der Bij, $\mathrm{H}$ & 42 & 1 & 42.0 & van Burg, E & 14 & 2 & 7.0 \\
\hline Doganova, L & 40 & 1 & 40.0 & Baker, $\mathrm{T}$ & 13 & 1 & 13.0 \\
\hline Eyquem-Renault, M & 40 & 1 & 40.0 & Barr, SH & 13 & 1 & 13.0 \\
\hline Garnsey, E & 38 & 3 & 12.7 & Gilsing, VA & 13 & 1 & 13.0 \\
\hline Maine, E & 38 & 3 & 12.7 & Kingon, AI & 13 & 1 & 13.0 \\
\hline Wright, M & 38 & 3 & 12.7 & Markham, SK & 13 & 1 & 13.0 \\
\hline Chang, PL & 32 & 1 & 32.0 & Romme, AGL & 13 & 1 & 13.0 \\
\hline Shih, HY & 32 & 1 & 32.0 & & & & \\
\hline
\end{tabular}

As can be seen, geographically, the highest ratios are found in co-authoring institutions within the U.S. Although less expressive, the following international coauthorships can also be highlighted: Simon Fraser University (Canada) and University of Cambridge (UK), with three co-authored papers; University of New Mexico (U.S.) and University of Twente (Netherlands); and Imperial College London (UK) and Ghent University (Belgium), both pairs with two co-authored publications.

\section{Conclusions and implications}

This study synthesizes insights from a significant portion of relevant studies in the TE area. Because it is not limited to the major journals in the field, it covers a broader range of subjects than previous studies. In this sense, the bibliometric analysis presented 
Table 4 Clusters of most cited authors (number of citations in brackets)

\begin{tabular}{lll}
\hline Cluster 1 & Cluster 2 & Cluster 3 \\
\hline Shane, S (53) & Schumpeter, J (34) & Teece, DJ (26) \\
Wright, M (26) & Eisenhardt, KM (27) & Rothaermel, FT (17) \\
Zahra, SA (26) & Linton, JD (15) & Cohen, WM (16) \\
Saxenian, A (21) & Rogers, EM (15) & Dushnitsky, G (16) \\
Acs, ZJ (18) & OECD (14) & Chesbrough, H (14) \\
Porter, M (18) & Freeman, C (13) & Zucker, LG (12) \\
Antoncic, B (17) & Nelson, RR (13) & Gompers, PA (11) \\
Garud, R (17) & Walsh, ST (11) & Katila, R (11) \\
Audretsch, DB (16) & Christensen, CM (10) & Stuart, TE (11) \\
Mitchell, RK (16) & Dodgson, M (10) & Arora, A (10) \\
Florida, R (14) & Maine, E (10) & \\
Aldrich, HE (12) & \\
Bruton, GD (12) & \\
Lockett, A (12) & \\
Cooper, A (11) & \\
Covin, JG (11) & \\
Storey, DJ (11) & \\
Gartner, WB (10) & \\
Phan, PH (10) & & \\
\hline & & \\
\hline
\end{tabular}

allows us to discuss the most significant progress achieved from 1986 through 2013, allowing further reflections and greater versatility in TE research to be achieved. Through systematic analyses of co-citation networks, which include intellectual structure, scientific journals, authors, affiliations and countries, this study also brings further coherence and scientific structure to the existing (and hitherto sparse) literature.

Despite increasing research, TE is still an emerging theoretical field ( $c f$. Phan and Foo 2004; Beckman et al. 2012). The division of TE into three approaches (cf. Table 2)

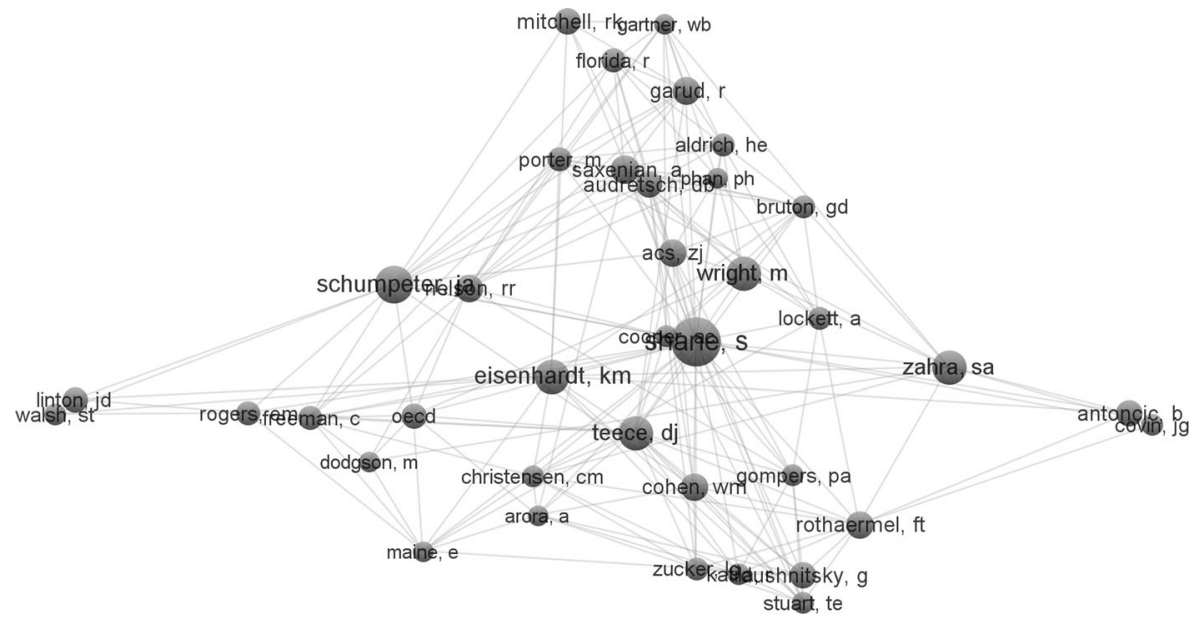

Fig. 4 Network of co-cited authors in the 135 articles and respective clusters 
Table 5 Top sources of citations in the field of TE

\begin{tabular}{|c|c|c|c|}
\hline & $\begin{array}{l}\text { Total } \\
\text { citations }\end{array}$ & $\begin{array}{l}\text { Total } \\
\text { articles }\end{array}$ & $\begin{array}{l}\text { Average citation } \\
\text { per article }\end{array}$ \\
\hline Research policy & 424 & 8 & 53.0 \\
\hline Journal of business venturing & 195 & 5 & 39.0 \\
\hline Technovation & 108 & 8 & 13.5 \\
\hline California management review & 105 & 2 & 52.5 \\
\hline Academy of management review & 55 & 1 & 55.0 \\
\hline Journal of product innovation management & 42 & 1 & 42.0 \\
\hline Journal of small business management & 38 & 3 & 12.7 \\
\hline Entrepreneurship theory and practice & 30 & 5 & 6.0 \\
\hline Academy of management learning \& education & 24 & 3 & 8.0 \\
\hline International journal of technology management & 21 & 5 & 4.2 \\
\hline Asia pacific journal of management & 20 & 2 & 10.0 \\
\hline Journal of technology transfer & 15 & 2 & 7.5 \\
\hline Ieee transactions on engineering management & 14 & 2 & 7.0 \\
\hline International journal of urban and regional research & 12 & 1 & 12.0 \\
\hline Technological forecasting and social change & 12 & 3 & 4.0 \\
\hline Information society & 9 & 1 & 9.0 \\
\hline International journal of engineering education & 4 & 1 & 4.0 \\
\hline Strategic management journal & 4 & 1 & 4.0 \\
\hline Entrepreneurship in emerging regions around the world & 3 & 2 & 1.5 \\
\hline International journal of manpower & 3 & 1 & 3.0 \\
\hline New technology work and employment & 3 & 1 & 3.0 \\
\hline Technology analysis \& strategic management & 3 & 2 & 1.5 \\
\hline Strategic entrepreneurship journal & 2 & 7 & 0.3 \\
\hline Asian journal of technology innovation & 2 & 1 & 2.0 \\
\hline Policy studies journal & 2 & 1 & 2.0 \\
\hline Public administration review & 2 & 1 & 2.0 \\
\hline Small business economics & 2 & 2 & 1.0 \\
\hline Production and operations manager & 1 & 1 & 1.0 \\
\hline
\end{tabular}

brought precision to its analysis. These approaches reflect the conditions that are conducive to the growth of TE. According to the institutional approach, the existence of institutions and the support for research that they can provide are key factors for the development of TE. The governmental and financial approach, in turn, argues that the development of high-tech companies is fundamental to the existence of governmental supporting policies, such as the corporate venture capital that motivates and sustains the onset of TE. The environmental approach argues that certain types of environments have unique features that boost the growth of entrepreneurship.

Given the growing scientific, academic and public policy relevance of TE, in-depth research grounded on a well-founded theoretically structure and on "invisible colleges" is critically important because the analysis and understanding of the intellectual 
Table 6 Clusters resulting from the most cited sources (number of citations in brackets)

\section{Cluster 1 - Management}

Strategic management journal (164)

Administrative science quarterly (95)

Academic management journal (93)

Academic management review (87)

Organization science (79)

Management sciences (68)

American journal of sociology (25)

Journal of finance (25)

Frontiers of entrepreneurship (24)

Journal of management (22)

Cluster 3 - Business

Technovation (109)

Technological forecast and social changes (56)

R\&d management (29)

Journal of business ethics (24)

Journal of product innovation management (23)

International journal of technology management (21)
Cluster 2 - Management \& Entrepreneurship

Journal of business venturing (224)

Entrepreneurship theory and practice (69)

Journal of technology transfer (28)

International small business journal (24)

Journal of management studies (23)

Journal of small business management (20)

Cluster 4 - Environmental, Planning \& Development Studies

Research policy (224)

American economic review (41)

Small business economics (37)

Industrial and corporate change (32)

Regional studies (29)

Harvard business review (25)

framework underlying the study of TE in "invisible colleges" can be useful for a wide range of individuals, including students and academics (Powell et al. 1996; Shane 2004; Wright et al. 2004). Based on this premise, having a map of the conceptual framework of a discipline can be of great interest in the pursuit of a holistic view of a field of study, improving our understanding of relationships between paradigms and the most analyzed topics and, thus, identifying essential work still to be done (Casillas and Acedo 2007; Teixeira 2011; McMillan 2008). Furthermore, the possibility of summarizing the

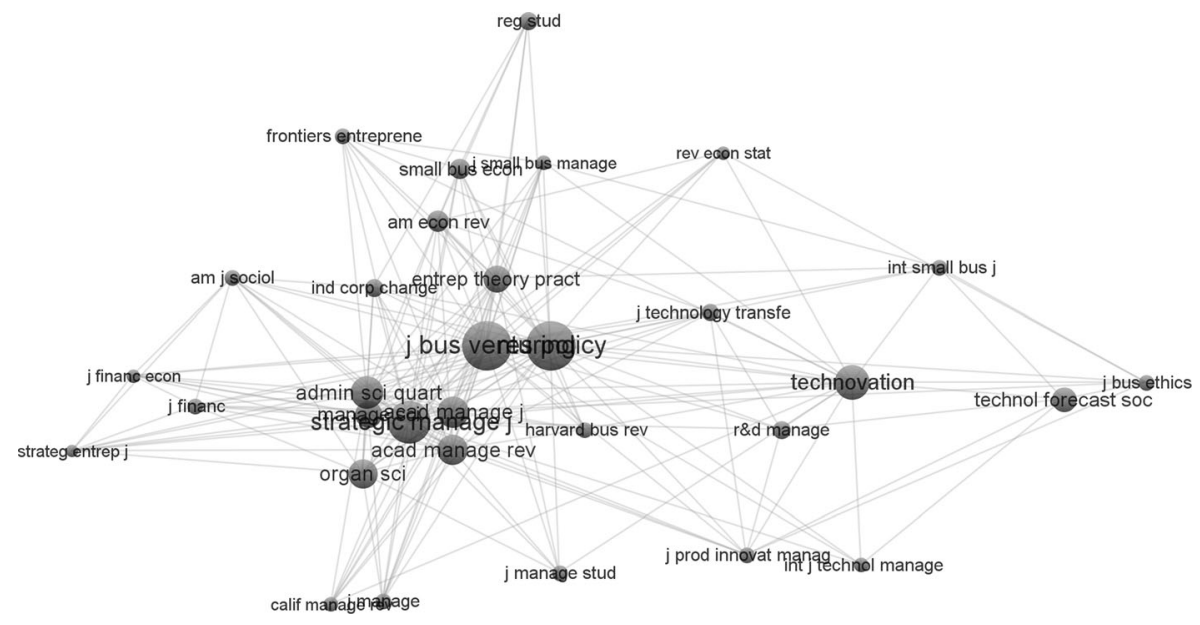

Fig. 5 Network of co-cited sources in the 135 initial articles and respective clusters 
Table 7 Top institutions with co-authored publications in the field of TE

\begin{tabular}{lll}
\hline Institution 1 & Number of articles & Institution 2 \\
\hline Simon Fraser University (Canada) & 3 & University of Cambridge (England) \\
University of New Mexico (USA) & 2 & University of Twente (Nederland) \\
University of Washington (USA) & 2 & Oregon University System (USA) \\
University of Washington (USA) & 2 & Stanford University (USA) \\
University of Washington (USA) & 2 & University of California System (USA) \\
University of Washington (USA) & 2 & Stanford University (USA) \\
Georgia Institute of Technology (USA) & 2 & California State University System (USA) \\
Imperial College London (England) & 2 & Ghent University (Belgium) \\
\hline
\end{tabular}

relevant literature and the relationships between fundamental works in the area enables researchers to position their research within the field of study and to identify creative and influential niches of research in the field of TE (Etemad and Lee 2003; Gartner et al. 2006). In our research, we found that, geographically, the highest number of co-authoring relationships is found in institutions within the U.S. and international co-authorships are less frequent. In international co-authorship, we highlight Simon Fraser University (Canada) and the University of Cambridge (UK), with three co-authored articles, as well as the University of New Mexico (U.S.) and the University of Twente (Netherlands) and the Imperial College London (UK) and Ghent University (Belgium), in both cases with two co-authored articles. We have also noticed that the internationalization of the scientific community in this research field is still fairly limited. Research on TE is concentrated in only a few countries - the U.S., UK and Netherlands with uncontested hegemony from the U.S. In light of these results, internationalization is a challenge that arises as essential for a truly networked community, which should not be overlooked or omitted in scientific terms.

Because the use of bibliometric studies is not yet well established in the field of TE, a major contribution of our study is to provide a more systematic approach to the literature review in this field. Despite the challenges in this type of systematization, which stem from the variety of articles analyzed, the results show that TE is an emergent and evolving research field (for further discussion, see Nelson 1982; Eisenhardt 1989; Eisenhardt and Schoonhoven 1990; Porter 1990; Roberts 1991; Nelson and Rosenberg 1993; Rogers 1995; Shane and Venkataraman 2000). One should bear in mind, however, that the analysis presented in this study covers a variety of studies and, thus, a variety of methods for analyzing the TE phenomenon, creating potential threats in terms of generalization of the results. In this regard, careful consideration should be given to the ways in which the articles on TE were obtained. The data collection was conducted using the ISI Web of Science database (i.e., we did not consider other important databases) and involved articles published in journals exclusively allocated to the categories of management, business and economics, without the use of any chronological filter. While this can be considered an important limitation, one should bear in mind, however, that this study brings new insights to the field of TE (e.g., progress in the field, leading authors, research lines and geographic distribution), since it examines data from co-citations and uses a quantitative approach 
that allows scientific publications to be mapped, and an (new) intellectual framework and research trends related to TE to be plotted. In this sense, and despite its limitations, this study is one of the first attempts to systematically map the research on TE using bibliometric tools. The analysis of 135 scientific articles contributes to the literature on $\mathrm{TE}$, and the structured form of the analysis provides a solid basis for how to conceptualize TE in future research.

This paper thus contributes to the existing literature providing insights about what we know about technology research. We are aware, however, that not all issues have been put to rest. In particular, it would be of particular interest to reinforce the literature review and examine more recent and/or less cited publications that might not have been included in our sample. This would allow potential alternative theories on TE to be detected and/or better understood, complementing the results obtained here. In this regard, the analysis of articles exclusively devoted to entrepreneurship and/or their analysis using different methodological approaches can enhance our current knowledge on the field, providing insights/discussion/reflections not only about what we do, but also what we do not know about TE. In addition, future approaches to TE should act as bridges between economics and social sciences. This integration of the social sciences can be based on the principles of rational action, considering that rationality is built and supported on beliefs, culture and social values. TE institutions and networks should play a key role in integrating these theories.

In summary, the concept of TE has several interrelated facets. It is not just about discovery or speculation; it also involves creation. This creation occurs with the direct influence of different actors, suggesting that the process spreads among them with interpretive asymmetries that generate opportunities through creative synthesis. This means that these actors are embedded in the creative process itself, which is generated through the actors' direct involvement and supported by technology, giving rise to structures of knowledge which then act as platforms for further developments. Naturally, further research is ongoing and subsequent papers will provide a more in-depth analysis of the TE phenomenon. In light of this reasoning, we hope that researchers, policy-makers and practitioners in the field of TE can look beyond their immediate interests and boost the dynamics and growth of this particular research community. This is particularly relevant because of the increasing rate of publications in the area, the complexity of the review processes, and the permanent change of the methodological trends.

\section{References}

Aldrich, H. (1999). Organizations evolving. Thousand Oaks: Sage Publications Ltd.

Aldrich, H., \& Fiol, C. (1994). Fools rush in? The institutional context of industry creation. The Academy of Management Review, 19(4), 645-670.

Antoncic, B., \& Prodan, I. (2008). Alliances, corporate technological entrepreneurship and firm performance: testing a model on manufacturing firms. Technovation, 28(5), 257-265.

Audretsch, D., Keilbach, M., \& Lehmann, E. (2006). Entrepreneurship and economic growth. Oxford: Oxford University Press.

Bahrami, H., \& Evans, S. (1995). Flexible re-cycling and high-technology entrepreneurship. California Management Review, 37(3), 62-89.

Barney, J. (1991). Firm resources and sustained competitive advantage. Journal of Management, 17(1), 99-120. 
Barr, S., Baker, T., Markham, S., \& Kingon, A. (2009). Bridging the valley of death: lessons learned from 14 years of commercialization of technology education. Academy of Management Learning and Education, $8(3), 370-388$.

Baumol, W. (1968). Entrepreneurship in economic theory. American Economic Review: Papers and Proceedings, 58(2), 64-71.

Baumol, W. (1993). Formal entrepreneurship theory in economics: existence and bounds. Journal of Business Venturing, 8(3), 197-210.

Baumol, W. (2005). Entrepreneurship and Innovation: Toward their Microeconomic Value Theory. AEIBrookings Joint Center for Regulatory Studies.

Baumol, W., Litan, E., \& Schramm, J. (2007). Good capitalism, Bad capitalism and the economics of growth and prosperity. New Haven: Yale University Press.

Beckman, C., Eisenhardt, K., Kotha, S., Meyer, A., \& Rajagopalan, N. (2012). Technology entrepreneurship. Strategic Entrepreneurship Journal, 6(2), 89-93.

Bhide, A. (2000). The Origin and Evaluation of New Business. Oxford University Press.

Bijker, W., \& Law, J. (1992). Shaping technology/building society: Studies in sociotechnical change. Cambridge: MIT Press.

Bijker, W., Hughes, T., \& Pinch, T. (1987). The social construction of technological systems: New directions in the sociology and history of technology. Cambridge: MIT Press.

Braun, E., \& Macdonald, S. (1982). Revolution in miniature: The history and impact of semiconductor electronics re-explored. New York: Cambridge University Press.

Bruton, G., \& Rubanik, Y. (2002). Resources of the firm, Russian high-technology startups, and firm growth. Journal of Business Venturing, 17(6), 553-576.

Casillas, J., \& Acedo, F. (2007). Evolution of the intellectual structure of family business literature: a bibliometric study of FBR. Family Business Review, 20(2), 141-162.

Casson, M. (1982). The entrepreneur: An economic theory. Totowa: Barnes \& Noble Books.

Casson, M. (1987). The firm and the market: Studies on multinational enterprise and the scope of the firm. Cambridge: MIT Press.

Casson, M. (1995). Entrepreneurship and business culture: Studies in the economics of trust. Brookfield: Edward Elgar.

Casson, M. (1997). Information and organization: A new perspective on the theory of the firm. Oxford: Claredon Press.

Casson, M. (2003). The entrepreneur: An economic theory. 2nd edition, Cheltenham, UK and Northanpton. MA: Edward Elgar.

Chang, P., \& Shih, H. (2004). The innovation systems of Taiwan and china: a comparative analysis. Technovation, 24(7), 529-539.

Cohen, W., \& Levinthal, D. (1990). Absorptive capacity: a new perspective on learning and innovation. Administrative Science Quarterly, 35(1), 128-152.

Di Guardo, M., \& Harrigan, K. (2012). Mapping research on strategic alliances and innovation: a co-citation analysis. The Journal of Technology Transfer, 37(6), 789-811.

DiMaggio, P., \& Powell, W. (1983). The iron cage revisited: collective rationality and institutional isomorphism in organizational fields. American Sociological Review, 48(2), 147-60.

Dodgson, M. (2009). Asia's national innovation systems: institutional adaptability and rigidity in the face of global innovation challenges. Asia Pacific Journal of Management, 26(3), 589-609.

Doganova, L., \& Eyquem-Renault, M. (2009). What do business models do? Innovation devices in technology entrepreneurship. Research Policy, 38(10), 1559-1570.

Dushnitsky, G., \& Lenox, M. (2005a). When do firms undertake R\&D by investing in new ventures? Strategic Management Journal, 26(10), 947-965.

Dushnitsky, G., \& Lenox, M. (2005b). When do incumbents learn from entrepreneurial ventures? Research Policy, 34(5), 615-639.

Eisenhardt, K. (1989). Building theories from case study research. The Academy of Management Review, 14(4), 532-550.

Eisenhardt, K., \& Schoonhoven, C. (1990). Organizational growth: linking founding team, strategy, environment, and growth among US semiconductor ventures, 1978-1988. Administrative Science Quarterly, 35(3), 504-529.

Etemad, H., \& Lee, Y. (2003). The knowledge network of international entrepreneurship: theory and evidence. Small Business Economics, 20(1), 5-23.

Florida, R., \& Kenney, M. (1988). Venture capital and high technology entrepreneurship. Journal of Business Venturing, 3(4), 301-319. 
Gans, J., \& Stern, S. (2003). The product market and the market for "ideas": commercialization strategies for technology entrepreneurs. Research Policy, 32(2), 333-350.

Gartner, W., Davidsson, P., \& Zahra, S. (2006). Are you talking to me? The nature of community in entrepreneurship scholarship. Entrepreneurship: Theory and Practice, 30(3), 321-331.

Garud, R. (1997). On the distinction between know-how, know-why and know-what in technological systems. In J. Walsh \& A. Huff (Eds.), Advances in strategic management (pp. 81-101). Greenwich: JAI Press.

Garud, R., \& Karnøe, P. (2003). Bricolage versus breakthrough: distributed and embedded agency in technology entrepreneurship. Research Policy, 32(2), 277-300.

Garud, R., \& Rappa, M. (1994). A socio-cognitive model of technology evolution. Organization Science, 5(3), $344-362$.

Garud, R., \& Van de Ven, A. (1987). Innovation and the emergence of industries. Proceedings of the Academy of Management National Meeting, New Orleans, (pp. 319-322).

Garud, R., Kumaraswamy, A., \& Nayyar, P. (1998). Real options or fool's gold: perspective makes the difference. Academy of Management Review, 3(2), 212-214.

Gilsing, V., van Burg, E., \& Romme, A. (2010). Policy principles for the creation and success of corporate and academic spin-offs. Technovation, 30(1), 12-23.

Harper, D. (1996). Entrepreneurship and the market process. London: Routlidge.

Hébert, R., \& Link, A. (1982). The entrepreneur. New York: Praeger.

Hébert, R., \& Link, A. (2009). A history of entrepreneurship. Milton Park: Routledge.

Karnøe, P. (1993). Approaches to innovation in modern wind energy technology: Technology policies, science, engineers and craft traditions. Stanford: Center for Economic Policy Research Publication, Publication 334.

Kassicieh, S., Radosevich, H., \& Banbury, C. (1997). Using attitudinal, situational, and personal characteristics variables to predict future entrepreneurs from national laboratory inventors. IEEE Transactions on Engineering Management, 44(3), 248-257.

Kirzner, I. (1997). Entrepreneurial discovery and the competitive market process: an Austrian approach. Journal of Economic Literature, 35(1), 60-85.

Kline, R., \& Pinch, T. (1996). Users as agents of technological change: the social construction of automobile in the rural United States. Technology and Culture, 37(4), 763-779.

Knight, F. (2002). Risk, uncertainty and profit. Boston: Houghton Mifflin Company.

Landström, H. (2005). Pioneers in entrepreneurship and small business research. New York: Springer.

Landström, H., \& Benner, M. (2010). Entrepreneurship research: A history of scholarly migration. In H. Landström \& F. Lohrke (Eds.), Historical foundations of entrepreneurship research (pp. 15-45). Cheltenham: Edward Elgar.

Latour, B. (1991). Technology is society made durable. In J. Law (Ed.), A sociology of monsters: Essays on power, technology and domination. London: Routledge.

Lievrouw, L. (1989). The invisible college reconsidered: bibliometrics and the development of scientific communication theory. Communication Research, 16(5), 615-628.

Maine, E., \& Garnsey, E. (2006). Commercializing generic technology: the case of advanced materials ventures. Research Policy, 35(3), 375-393.

McMillan, S. (2008). Mapping the invisible colleges of R\&D management. R\&D Management, 38(1), 69-83.

Melkers, J., Bulger, D., \& Bozeman, L. (1993). Technology transfer and economic development. In R. Bingham \& R. Mier (Eds.), Theories of local economic development. Newbury Park: Sage.

Mises, L. (1978). Planning for freedom. South Holland: Libertarian Press.

Morris, A., \& Lowder, S. (1992). Flexible specialization: the application of theory in a poor country context: Leon, Mexico. International Journal of Urban \& Regional Research, 16(2), 190-201.

Mustar, P., \& Wright, M. (2010). Convergence or path dependency in policies to foster the creation of university spin-off firms? A comparison of France and the United Kingdom. Journal of Technology Transfer, 35(1), 42-65.

Nacu, C., \& Avasilcăi, S. (2014). Environmental factors influencing technological entrepreneurship: research framework and results. Procedia - Social and Behavioral, 109, 1309-1315.

Neck, H., Meyer, G., Cohen, B., \& Corbett, A. (2004). An entrepreneurial system view of new venture creation. Journal of Small Business, 42(2), 190-208.

Nelson, R. (1982). An evolutionary theory of economic change. Cambridge: Harvard University Press.

Nelson, R., \& Rosenberg, N. (1993). Technical innovation and national systems. National innovation systems: A comparative analysis. Oxford: Oxford University Press.

Parker, S. (2005). The economics of entrepreneurship: what we know and what we don't. Foundations and Trends in Entrepreneurship, 1(1), 1-54. 
Phan, P., \& Foo, M. (2004). Technological entrepreneurship in emerging regions. Journal of Business Venturing, 19(1), 1-5.

Porter, M. (1990). The competitive advantage of nations. Harvard Business Review, 68(2), 73-93.

Powell, W., Koput, K., \& Smith-Doerr, L. (1996). Interorganizational collaboration and the locus of innovation: networks of learning in biotechnology. Administrative Science Quarterly, 41(1), 116-145.

Price, S. (1963). Little science, big science. New York: Columbia University Press.

Price, S. (1971). Some remarks on elitism in information and the invisible college phenomenon in science. Journal of the American Society for Information Science, 22(2), 74-75.

Roberts, E. (1991). Entrepreneurs in high technology. New York: Oxford University Press.

Rogers, E. (1995). Diffusion of Innovations. Retrieved from http://www.d.umn.edu/ /rochfor/ireland/dif-of-inch06.pdf November 2013.

Rosenberg, N. (1982). Inside the black box: Technology and economics. New York: Cambridge University Press.

Schramm, J. (2006). The entrepreneurial imperative: How America's economic miracle will reshape the world (and change your life). New York: HarperCollins.

Schumpeter, J. (1934). The theory of economic development. New Jersey: Transaction Publishers.

Schumpeter, J. (1942). Socialism, capitalism and democracy. New York: Row.

Segal, N. (1986). Universities and technological entrepreneurship in Britain: some implications of the Cambridge phenomenon. Technovation, 4(3), 189-204.

Shane, S. (2000). Prior knowledge and the discovery of entrepreneurial opportunities. Organization Science, 11(4), 448-469.

Shane, S. (2004). Academic entrepreneurship. Cheltenham: Edward Elgar Publishing.

Shane, S., \& Venkataraman, S. (2000). The promise of entrepreneurship as a field of research. Academy of Management Review, 25(1), 217-227.

Shane, S., \& Venkataraman, S. (2003). Guest editors' introduction to the special issue on technology entrepreneurship. Research Policy, 32(2), 181-184.

Small, H. (1973). Co-citation in the scientific literature: a new measure of the relationship between two documents. Journal of the American Society for Information Science, 24(4), 265-269.

Smilor, R., \& Feeser, H. (1991). Chaos and the entrepreneurial process: patterns and policy implications for technology entrepreneurship. Journal of Business Venturing, 6(3), 165-172.

Smith, L. (1981). Citation analysis. Library Trends, 30(1), 83-106.

Song, M., \& Podoynitsyna, K. (2008). Success factors in new ventures: a meta-analysis. The Journal of Product Innovation Management, 25(1), 7-27.

Spencer, J., Murtha, T., \& Lenway, S. (2005). How governments matter to new industry creation. Academy of Management Review, 30(2), 321-337.

Spulber, D. (2009). The theory of the firm: Microeconomics with endogenous entrepreneurs, firms, markets and organizations. Cambridge: Cambridge University Press.

Spulber, D. (2011). The innovator's decision: Entrepreneurship versus technology transfer. In D. Audretsch, O. Falk, S. Heblich, \& A. Lederer (Eds.), Handbook of research on innovation and entrepreneurship. Cheltenham: Edward Elgar.

Storper, M. (1995). The resurgence of regional economics, ten years later: the region as a nexus of untreated interdependencies. European Urban and Regional Studies, 2(3), 191-221.

Stuart, T., Hoang, H., \& Hybels, R. (1999). Interorganizational endorsements and the performance of entrepreneurial ventures. Administrative Science Quarterly, 44(2), 315-349.

Swedberg, R. (2000). Entrepreneurship. The social science view. Oxford: Oxford University Press.

Tan, J., Fischer, E., Mitchell, R., \& Phan, P. (2009). At the center of the action: Innovation and technology strategy research in the small business setting. Journal of Small Business Management, 47(3), 233-262.

Teece, D. (1986). Profiting from technological innovation: implications for integration, collaboration, licensing and public policy. Research Policy, 15(6), 285-305.

Teece, D. (1987). Profiting from technological innovation: implications for integration, collaboration, licensing and public policy. In D. Teece (Ed.), The competitive challenge: Strategies for industrial innovation and renewal (pp. 185-219). Cambridge: Ballinger.

Teece, D. (1998). Research directions for knowledge management. California Management Review, 40(3), 289-292.

Teece, D., Pisano, G., \& Shuen, A. (1997). Dynamic capabilities and strategic management. Strategic Management Journal, 18(7), 509-533.

Teixeira, A. (2011). Mapping the (in)visible college(s) in the field of entrepreneurship. Scientometrics, 89(1), $1-36$. 
Thomsom, R. (2008). Using Bibliometrics: A Guide to Evaluating Research Performance with Citation Data, Retrieved from http://ip-science.thomsonreuters.com/m/pdfs/325133_thomson.pdf January 2014.

Tierney, R., Hermina, W., \& Walsh, S. (2013). The pharmaceutical technology landscape: a new form of technology road mapping. Technological Forecasting and Social Change, 80(2), 194-211.

Tomes, A., Erol, R., \& Armstrong, P. (2000). Technological entrepreneurship: integrating technological and product innovation. Technovation, 20(3), 115-127.

Tripsas, M. (2001). Understanding the timing of technological transitions: the role of user preference discontinuities. Proceedings of the Academy of Management Meetings, Washington, DC.

Tushman, M., \& Anderson, P. (1986). Technological discontinuities and organizational environments. Administrative Science Quarterly, 31(3), 439-465.

Usher, A. (1954). A history of mechanical inventions. Cambridge: Harvard University Press.

Van Eck, N., \& Waltman, L. (2009). How to normalize concurrence data? An analysis of some well-known similarity measures. Journal of the American Society for Information Science and Technology, 60(8), $1635-1651$.

Van Eck, N., \& Waltman, L. (2010). Software survey VOSviewer: a computer program for bibliometric mapping. Scientometrics, 84(2), 523-538.

Venkataraman, S. (1997). The distinctive domain of entrepreneurship research. In J. Katz \& J. Brockhaus (Eds.), Advances in entrepreneurship, firm emergence and growth (pp. 119-138). Greenwich: JAI Press.

Venkataraman, S. (2004). Regional transformation through technological entrepreneurship. Journal of Business Venturing, 19(1), 153-167.

Verbeek, A., Debackere, K., Luwel, M., \& Zimmermann, E. (2002). Measuring progress and evolution in science and technology - I: the multiple uses of bibliometric indicators. International Journal of Management Reviews, 4(2), 179-211.

Von Hippel, E. (1986). Lead users: a source of novel product concepts. Management Science, 32(7), 791-805.

Walsh, T., \& Kirchhoff, A. (2002). Technology transfer from government labs to entrepreneurs. Journal of Enterprising Culture, 10(2), 133-149.

Waltman, L., Van Eck, N., \& Noyons, E. (2010). A unified approach to mapping and clustering of bibliometric networks. Journal of Informetrics, 4(4), 629-635.

White, H., \& McCain, K. (1998). Visualizing a discipline: an author co-citation analysis of information science 1972-1995. Journal of the American Society for Information Science, 49(4), 327-355.

Wong, P. (2003). Global and national factors affecting e-commerce diffusion in Singapore. The Information Society, 19(1), 19-32.

Wright, M., Birley, S., \& Mosey, S. (2004). Entrepreneurship and university technology transfer. Journal of Technology Transfer, 29(3/4), 235-246.

Wright, M., Hmieleski, K., Siegel, D., \& Ensley, M. (2007). The role of human capital in technological entrepreneurship. Entrepreneurship: Theory and Practice, 31(6), 791-806.

Yanez, M., Khalil, T., \& Walsh, S. (2010). IAMOT and education: defining a technology and innovation management (TIM) body-of-knowledge (BoK) for graduate education (TIM BoK). Technovation, $30(7 / 8), 389-400$.

Zitt, M., \& Bassecoulard, E. (1994). Development of a method for detection and trend analysis of research fronts built by lexical or cocitation analysis. Scientometrics, 30(1), 333-351.

Zuccala, A. (2006). Modeling the invisible college. Journal of the American Society for Information Science and Technology, 57(2), 152-168.

Zucker, L., Darby, M., \& Brewer, M. (1998). Intellectual human capital and the birth of U.S. biotechnology enterprises. American Economic Review, 88(1), 290-30. 